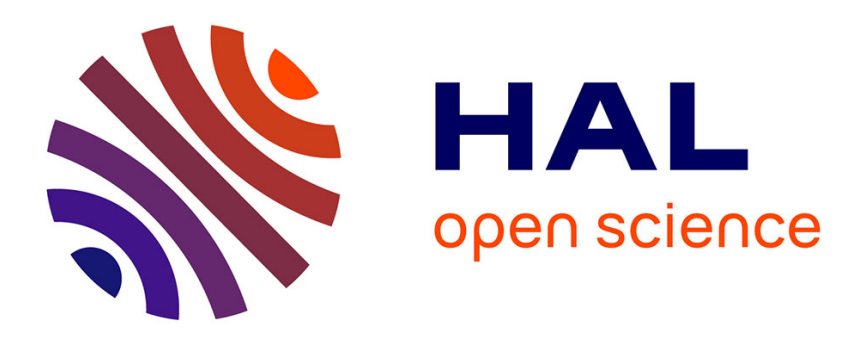

\title{
Microbial interactions in cheese: implications for cheese quality and safety
}

Françoise Irlinger, Jérôme Mounier

\section{To cite this version:}

Françoise Irlinger, Jérôme Mounier. Microbial interactions in cheese: implications for cheese quality and safety. Current Opinion in Biotechnology, 2009, 20 (2), pp.142-148. 10.1016/j.copbio.2009.02.016 . hal-00557069

\section{HAL Id: hal-00557069 \\ https://hal.univ-brest.fr/hal-00557069}

Submitted on 21 Jan 2011

HAL is a multi-disciplinary open access archive for the deposit and dissemination of scientific research documents, whether they are published or not. The documents may come from teaching and research institutions in France or abroad, or from public or private research centers.
L'archive ouverte pluridisciplinaire HAL, est destinée au dépôt et à la diffusion de documents scientifiques de niveau recherche, publiés ou non, émanant des établissements d'enseignement et de recherche français ou étrangers, des laboratoires publics ou privés. 
Opinion in Biotechnology

Elsevier Editorial System(tm) for Current

Manuscript Draft

Manuscript Number: COBIOT-D-09-00010R2

Title: Microbial interactions in cheese: implications for cheese quality and safety

Article Type: Food biotechnology 20/2

Corresponding Author: Dr. Françoise Irlinger, Ph.D.

Corresponding Author's Institution: INRA, Institut National de la recherche Agronomique

First Author: Françoise Irlinger, Ph.D.

Order of Authors: Françoise Irlinger, Ph.D.; Jérome Mounier, Ph.D. 


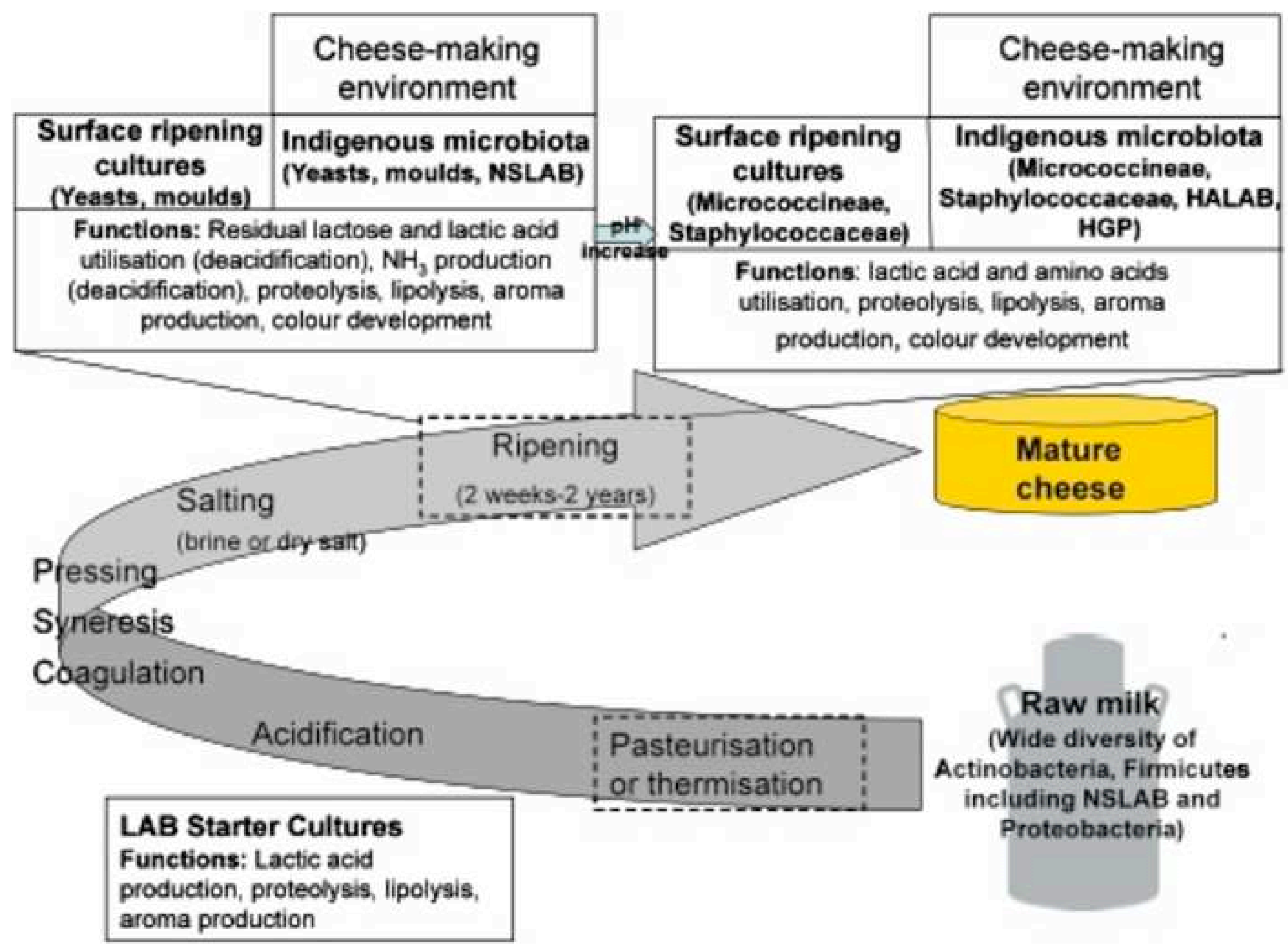

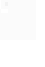
ndigenous microbiota LAB Starter Cu
Functions: Lactic
production, protec
aroma production Pasteurisation $\sqrt{2}$

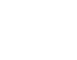

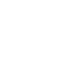

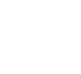

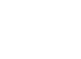
. . .

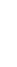

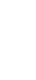


Figure 1. Schematic overview of the microbial succession and the functions of the different microbial groups involved during cheese-making. Abbreviations: LAB, lactic acid bacteria; NSLAB, non-starter LAB; HALAB, halophilic and alkaliphilic LAB; HGP, moderately halophilic Gamma-Proteobacteria.!-- J, Non-obligatory processing step.

Figure 1.

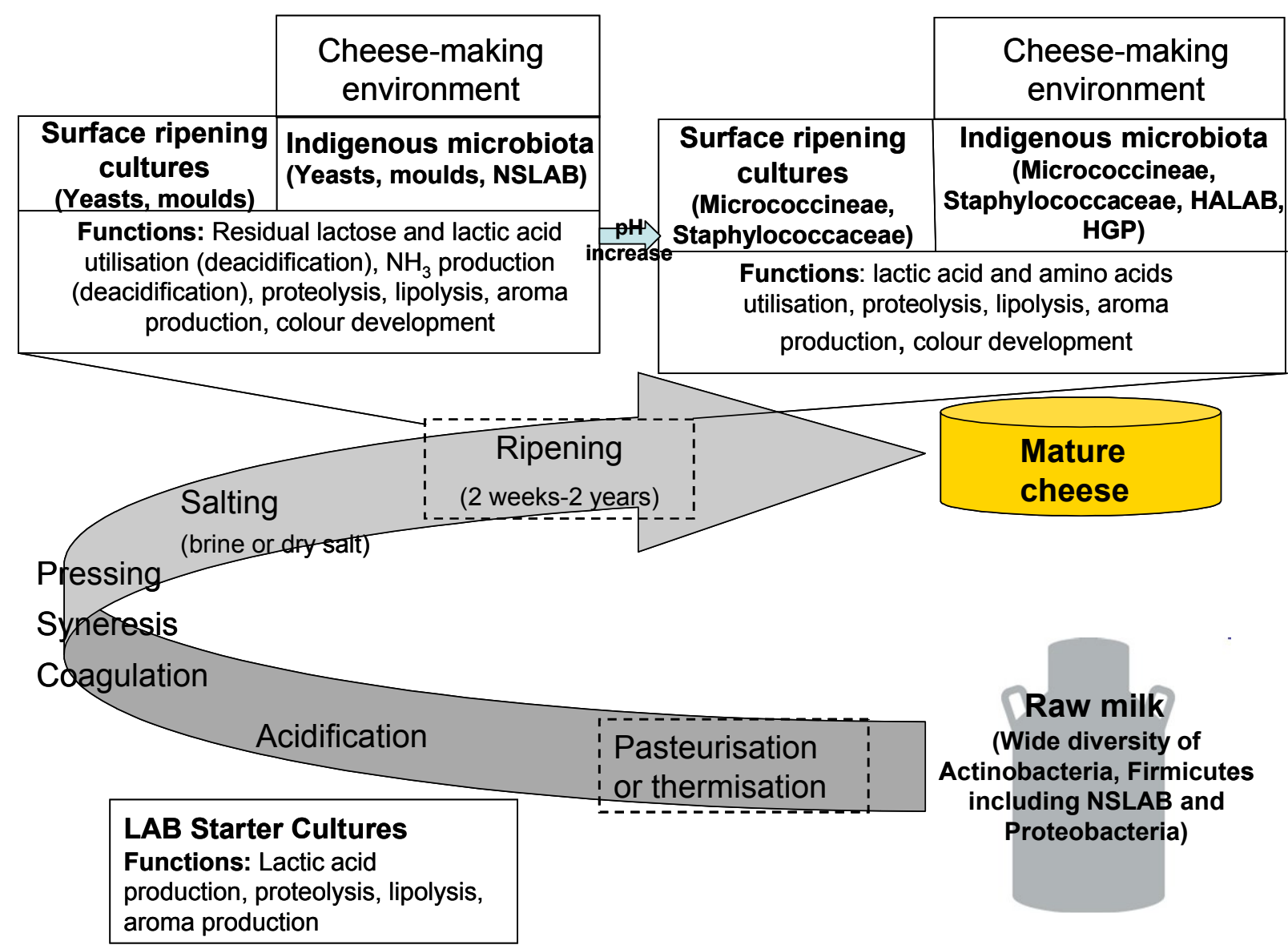




\section{Microbial interactions in cheese: implications for cheese quality and safety}

Françoise Irlinger $^{1 *}$ and Jérome Mounier ${ }^{2,3}$

\section{Addresses}

${ }^{1}$ UMR782 Génie et Microbiologie des Procédés Alimentaires, INRA, AgroParisTech, 78850 Thiverval Grignon, France

${ }^{2}$ Université Européenne de Bretagne, France

${ }^{3}$ Université de Brest, EA3882 Laboratoire Universitaire de Biodiversité et Ecologie

Microbienne, IFR148 ScInBioS, ESMISAB, Technopôle de Brest Iroise, 29280 Plouzané, France.

$\underline{\text { Running title: Microbial interactions in cheese }}$

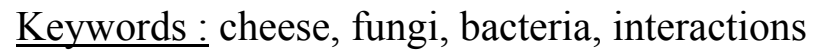

* Corresponding author:

E-mail: irlinger@grignon.inra.fr. 


\section{Summary}

The cheese microbiota, whose community structure evolves through a succession of different microbial groups, plays a central role in cheese-making. The subtleties of cheese character, as well as cheese shelf-life and safety, are largely determined by the composition and evolution of this microbiota. Adjunct and surface-ripening cultures marketed today for smear cheeses are inadequate for adequately mimicking the real diversity encountered in cheese microbiota. The interactions between bacteria and fungi within these communities determine their structure and function. Yeasts play a key role in the establishment of ripening bacteria. The understanding of these interactions offers to enhance cheese flavor formation and to control and/or prevent the growth of pathogens and spoilage microorganisms in cheese.

\section{Introduction}

There are over 1,000 varieties of cheeses produced on artisanal and industrial scales. The associated microbiota contributes to the biopreservation and the development of organoleptic properties of cheeses. Therefore, unravelling the microbial diversity and the functioning of these ecosystems is an extraordinary challenge to more effectively control the quality and safety of cheeses. A higher degree of microbiological safety in cheeses is yet to be achieved [1]. A recent study [1], revealed that in $2 \%$ of marketed cheeses made from raw, thermised and pasteurized cheeses, counts of Escherichia coli, Staphylococcus aureus, and/or Listeria monocytogenes were above those allowed by the European Commission Recommendations 2004/24/EC and 2005/175/EC.

This review summarises our current knowledge of microbial biodiversity and interactions within these cheese communities. Central to the discussion is the recent progress made in the understanding of ecological interactions within the different components of the cheese microbiota. We end with a discussion on how these interactions may improve cheese safety and quality and the new challenges facing researchers, cheese-makers and cheese cultures manufacturers.

\section{Cheese-making and microbial diversity}

Two reviews entirely devoted to culture-independent methods available for the description of the bacterial and fungal communities in cheeses have recently been published $[2,3]$. Most 
cheeses harbour a complex microbiota that is characterised by a succession of microbial groups during milk fermentation, curd maturation and storage (Figure 1).

At the beginning of the cheese-making process, lactic acid bacteria (LAB) starter cultures (i.e. Lactococcus lactis, Streptococcus thermophilus) grow rapidly and produce acid in milk [4]. During the first days of ripening, yeasts and/or moulds (i.e. Debaryomyces hansenii, Geotrichum candidum, Penicillium camemberti) colonize the surfaces of cheese and utilize lactate [5]. This leads to the deacidification of the cheese surface, enabling the establishment of a bacterial community which is less acid-tolerant (i.e. Arthobacter arilaitensis, Brevibacterium aurantiacum, Brevibacterium linens, Corynebacterium casei) [6, 7, 8, 9, 10, $11,12]$. Studies of traditional smear cheeses have also revealed the presence of moderately halophilic $\delta$-Proteobacteria i.e. Halomonas spp., bacteria from the Enterobacteriaceae family (i.e. Hafnia alvei), and halophilic and alkaliphic LAB i.e. Marinilactibacillus psychrotolerans or Alkalibacterium olivapovliticus. The roles of these organisms in cheese ripening have not yet been determined [13, 14].

\section{Understanding the ripening process through the study of microbial interactions}

Cheese has a highly heterogeneous physicochemical composition that offers the possibility for the simultaneous occupation of multiple niches by "specialised" strains, i.e. through the utilisation of different carbon sources. Coexisting yeasts and bacteria often reach high population densities, typically between 8 and 10 logs colony-forming unit (CFU) per gram of cheese at the time of consumption. While the inventory and the succession of yeasts, moulds and bacteria have been well described, functional features of these different populations are still not understood in detail. Today, most of the interactions identified in cheeses are related to lactic acid bacteria because of a knowledge of their physiology and the recent publications of genome sequences of several species of LAB [15]. The mechanisms of interactions between LAB and other microorganisms have been extensively reviewed (Table 1 and [15]) and will not be considered further in this review.

Yeast, moulds and bacteria have been selected as cheese surface ripening cultures by the industry because of their interesting technological properties such as aroma or pigmentation. 
Recent investigations revealed, however, that these commercial ripening cultures do not establish well on cheese surfaces. For example, B. linens, the mostly commonly used bacterium in ripening cultures, was not found to establish successfully in various European cheeses $[7,16]$. Indeed, this bacterium did not compete well with the indigenous microflora present in the cheese-making equipment and environment [17].

These findings underline the fact that attention must be paid to the ecological adaptation of strains used for cheese inoculation, to their colonization capabilities or their ability to resist and/or adapt to disturbance (environmental conditions, contamination by a pathogen etc.) and to the interactions occurring between microorganisms. Indeed, the addition of microorganisms that express a specific function in pure culture, does not lead necessarily to a similar phenotype in microbial association. This reveals the limits of a strategy based on the addition of single strains to complex cheese surface microbiota.

Until recently, all the studies on the growth behaviour of microorganisms from cheese surfaces have been done on mixed cultures with only two microorganisms. An alternative strategy has been recently proposed to identify interactions within a microbial ecosystem in model smear cheeses [18]. The three-step strategy consisted of i) using a model ecosystem of nine species that was previously shown to have great similarities with the odor profile of a Livarot cheese, ii) describing the growth dynamics of each member of this community using the generalized Lotka-Volterra (GLV) model as a preliminary approach to represent inter- and intra-species interactions, and iii) omitting specific strains from this community to evaluate the consequences of these omissions on the development of the rest of the community. GLV modelling succeeded in representing yeast-bacterium interactions but did not succeed to represent bacterium-bacterium interactions because growth of most of the bacteria was highly correlated [18]. Nevertheless, these studies confirmed key role of yeast in bacterial development. These studies also demonstrated that commensalism between yeast and bacteria (Table 1). Indeed, the consumption of lactate and the production of alkaline metabolites such as ammonia from amino acid deamination by moulds and yeast, in particular, D. hansenii and G. candidum, leads to the deacidification of the cheese surface. This deacidification enables the outgrowth of less acid-tolerant, aerobic bacteria such as Arthrobacter spp, B. linens, C. casei, micrococci and staphylococci. 
Surface $\mathrm{pH}$ is not the only factor that influences bacterial development. The bacterial development and distribution of different species might be modified, depending on the yeast present in the ecosystem [18]. It appeared that the growth of some bacterial species such as $A$. arilaitensis and $H$. alvei relied on a deacidification function, whereas the growth of others such as B. aurantiacum and Leucobacter sp. relied on a specific yeast species [18]. Each one of the yeast species developed specific interactions with the other strains showing consequently a low redundancy between their functions. It is worth noting that only one inoculum level of yeasts and bacteria was tested in [18] and growth dynamics of this community may have changed with different inoculum levels.

Moreover, apart from inhibition e.g. amensalism through the production of antagonistic metabolites such as organic acids and/or bacteriocins (Table 1), growth suppression may result from non-specific competition between species for nutrients. This mechanism of inhibition has been described as the "Jameson effect" [19]. It can be described as a race between species to use the resources of the environment to maximise their growth and population numbers. When those resources are depleted, the race is over, and the growth of each species in the population stops. The Jameson effect is often observed in foods, particularly those in which lactic acid bacteria dominate the population due to a growth rate advantage. This mechanism was also identified in the inhibition of Listeria monocytogenes by the natural biofilm microbiota on wooden shelves used in the ripening of a smear cheese [20]. Indeed, the growth of $L$. monocytogenes stopped as soon as the biofilm microbiota entered in stationary phase. This effect was observed for two different inoculum levels of $L$. monocytogenes at two different times of inoculation in the biofilm [20].

It is also noteworthy that in dairy fermentations, nitrogen is limiting and organisms initially compete for the free amino acids and small peptides available in milk [15]. In the later stages of ripening, they compete for the peptides released by the actions of proteolytic enzymes. Thus, the ability to utilize amino acids efficiently is of primary importance in determining growth rate and population dynamics [15]. Moreover, micronutrients such as iron may be limiting for strains of smear cheeses. Consequently, siderophore-deficient isolates (Brevibacterium, Microbacterium spp., etc.) compete for iron through the use of specialised molecular systems for harvesting iron, including siderophores produced by microorganisms (Arthrobacter, Brevibacterium, Corynebacterium spp., etc.) [21]. This knowledge can be used to stimulate the growth of auxotrophic strains assigned to Brevibacterium sp., known to be a weak competitor in cheese manufacture. 
Microbes may also interact with and influence each others' metabolism through physical contact. Thus, in experimental cheese cultures when Yarrowia lipolytica was grown in association with G. candidum, hyphal formation was inhibited and G. candidum grew as spaghetti-like structures instead [18]. Ammonia and proline, produced in great quantities by $Y$. lipolytica, may influence yeast mycelium formation. Ammonia as a signalling molecule has been reported to be important for yeast colony survival and development $[22,23]$, but the molecular basis of these effects in complex environments such as cheese remains unclear.

\section{Implications of microbial interactions for food safety}

\section{Protective cultures}

In recent years, great efforts have been devoted to taking advantage of the antagonistic activities of microorganisms in cheese. For example, LAB cultures were used to prevent and control L. monocytogenes and spoilage microorganisms including Clostridium tyrobutyricum, within the framework of hurdle technology (e.g. milk pasteurisation, use of defined starter and ripening cultures) $[24,25,26]$. Protective cultures are used because they produce antagonistic metabolites such as bacteriocins, peptides and/or low-weight non-proteinaceous compounds (organic acids, fatty acids, $\mathrm{H}_{2} \mathrm{O}_{2}$, etc.) and differ from starter cultures that are mainly used for their technological functions (acid and aroma compound production). The recent developments of cheese cultures with protective functionalities and the limits of their utilisation (in situ production, developed resistance of the target organisms) have been recently reviewed [27] and are shown in Table 1. Finally, it is worth noting that very few commercial protective cultures are marketed today, underlining the difficulty to develop such cultures [27]. The restrictions on using GMOs in the European market also impede the development of more effective protective cultures.

\section{Hurdle effect of the cheese microbiota}

Most recent studies focused on the ability of the cheese microbiota to control and/or prevent the growth of L. monocytogenes in cheese [28, 9], as well as in the cheese-making environment [20]. The hurdle effect of complex microbiota on L. monocytogenes seems to be highly variable [28] and remains unclear at this time. It is probably related to multiple factors such as competitive interactions and/or synergistic effects of antagonistic metabolites produced in situ, such as organic acids, volatile compounds and $\mathrm{H}_{2} \mathrm{O}_{2}$. An innovative tool was recently developed for the screening the antilisterial cheese communities using PCR- Single 
Strand Conformation Polymorphism (SSCP) analysis by comparing the biodiversity profiles of distinct cheese microbiota from the same cheese variety and their antilisterial activity [9]. While three of the six members of cheese microbiota limited or prevented the growth of $L$. monocytogenes, none of the isolates from these cheeses produced any inhibitory substances towards L. monocytogenes in an agar diffusion assay [9].

\section{Implications of microbial interactions for food quality}

\section{Microbial interactions and cheese colour}

Cheese colour is an important criterion of acceptance by cheese consumers. This is especially true for red-smear cheeses which are characterised by the red-orange microbial mat on their surfaces. For a long time, it was believed that B. linens, because of its ability to produce carotenoids, was the main microorganism responsible for the colour development. The contribution of $B$. linens cannot be ruled out when this bacterium is present in high numbers. However, because of its sub-dominance in many traditional cheeses, it is unlikely that it is responsible for the colour development of the rind [16]. Today, it is believed that cheese colouration results from complex interactions between the components of the cheese surface microbiota [29]. The orange colour was most likely due to the interactions of yellowpigmented bacteria such as A. arilaitensis and Microbacterium spp., and other microorganisms such as orange-pigmented staphylococci and micrococci [17, 29], as well as yeast [18]. For example, pigment production in B. linens was found to vary as a function of the yeast used for deacidification [30]. Two cheeses with similar bacterial distribution and population had different surface-colour, implying that species-specific pigmentation of bacteria also differed depending on the yeasts present in a complex consortium [18].

\section{Taking advantage of microbial interactions to enhance cheese flavour formation}

Four pathways, e.g., glycolysis and the utilisation of citrate, proteolysis and lipolysis, are involved in cheese flavour formation [31,32]. Production of the flavour compounds relies on the milk-degrading enzymes of each strain, as well as on the complementation of metabolic pathways between strains, which may lead to an enhancement in the quantity and the variety of flavours. Therefore, functional diversity, which is closely related to the complexity of the cheese microbiota, plays a crucial role in the flavour compound multiplicity produced during ripening. 
Enhancing flavour formation has two major goals: (i) to shorten ripening time, and (ii) to improve cheese sensory quality. Different approaches have been proposed to achieve these goals. The first one is to select new adjunct cultures that are used in combination with the starter culture or the ripening culture. These adjunct cultures can enhance flavour formation because they produce enzymes that complement metabolic routes leading to aroma compounds [33, 34]. For example, S-methylthioacetate production was enhanced when a yeast Kluyveromyces lactis, able to produce esters and hence to accumulate acyl CoA, was cocultivated with $B$. linens, producing methanethiol [33]. There has also been a recent interest in studying flavouring capacities of Gram-negative bacteria such as Proteus vulgaris or Psychrobacter sp. that have been isolated from different traditional cheeses [35]. The second approach to enhancing flavour formation is the use of autolytic LAB cultures or, bacteriocinogenic cultures or bacteriocins to promote lysis of LAB, which increase proteolysis and, as a result, flavour formation [36, 37, 38].

\section{Future challenges}

The surface-ripening cultures marketed today are far from adequate for dealing with the diversity encountered in cheese microbiota and managing processes to support the growth of desirable microorganisms while preventing the undesirable ones. That is why understanding cheese microbial ecology is crucial to produce a product with a constant level of quality and safety. One solution for developing competitive and complex cultures would be to isolate and identify the desirable and dominant microorganisms within each cheese consortium and to return them to cheese-makers [39, 40, 41].

On the other hand, because cheese microbial communities are much less complex than environmental communities, they offer an ideal system to test new technologies. Indeed, the increasing number of available full genome sequences of cheese-related bacteria and fungi that are of industrial importance opens new routes to study their interactions in situ using comparative transcriptomic and proteomic approaches. Such studies pose technical challenges that need to be addressed, i.e., efficient RNA extraction from cheese [42, 43]. The application of metabolomic and metagenomic tools will also undoubtedly provide new insights into the understanding of the functioning of complex microbial communities (ecogenome) from cheese, but this has not yet been done.

\section{Glossary}


Clostridium tyrobutyricum is a spoilage organism responsible for flavour defects and late cheese blowing

Commensalism can be defined as a relationship between two species in which one benefits from the other while the other is unaffected [15] 
References and recommended reading

Papers of particular interest, published within the annual period of review, are indicated as follows:

- of special interest

$\bullet \bullet$ of outstanding interest

1. Little CL, Rhoades JR, Sagoo SK, Harris J, Greenwood M, Mithani V, Grant K, McLauchlin J: Microbiological quality of retail cheeses made from raw, thermized or pasteurized milk in the UK. Food Microbiol 2008, 25: 304-312.

2. Jany JL, Barbier G: Culture-independent methods for identifying microbial communities in cheese. Food Microbiol 2008, 25: 839-848.

3. Justé A, Thomma BPHJ, Lievens B: Recent advances in molecular techniques to study microbial communities in food-associated matrices and processes. Food Microbiol 2008, 25:745-761.

4. Delbès C, Ali-Mandjee L, Montel MC: Monitoring bacterial communities in raw milk and cheese by culture-dependent and-independent 16S rRNA gene-based analyses. Appl Env Microbiol 2007, 73:1882-1891.

5. Callon C, Delbès C, Duthoit F, Montel MC: Application of SSCP-PCR fingerprint to profile the yeast community in raw milk Salers cheeses. Syst Appl Microbiol 2006, 29:172180.

6. Rademaker JLW, Peinhopf M, Rijnen L, Bockelmann W, Noordman WH: The surface microflora dynamics of bacterial smear-ripened Tilsit cheese determined by T-RFLP DNA population fingerprint analysis. Int Dairy $J$ 2005, 15:785-794.

7. Rea MC, Goerges S, Gelsomino R, Brennan NM, Mounier J, Vancanneyt M, Scherer S, Swings J, Cogan TM: Stability of the biodiversity of the surface consortia of Gubbeen, a red-smear cheese. J Dairy Sci 2007, 90:2200-2210.

8. Belén Flórez A, Mayo B: PCR-DGGE as a tool for characterizing dominant microbial populations in the Spanish blue-veined Cabrales cheese. Int Dairy J 2006, 16:1205-1210

9. Saubusse M, Millet L, Delbès C, Callon C, Montel MC: Application of Single Strand Conformation Polymorphism-PCR method for distinguishing cheese bacterial communities that inhibit Listeria monocytogenes. Int J Food Microbiol 2007, 116:126135. 
10. Abriouel H, Martín-Platero A, Maqueda M, Valdivia E, Martínez-Bueno M: Biodiversity of the microbial community in a spanish farmhouse cheese as revealed by cultureindependent methods. Int J Food Microbiol 2008, 127:200-208.

11. Parayre S, Falentin H, Madec MN, Sivieri K, Le Dizes AS, Sohier D, Lortal S: Easy DNA extraction method and optimisation of PCR-Temporal Temperature Gel Electophoresis to identify the predominant high and low GC-content bacteria from dairy products. $J$ Microbiol Methods 2007, 63:431-441.

12. Licitra G, Ogier JC, Parayre S, Pediliggieri C, Carnemolla T, Falentin H, Madec MN, Carpino S, Lortal S: Variability of bacterial biofilms of the "Tina" wood vats used in the Ragusano cheese-making process. Appl Env Microbiol 2007, 73:6980-6987.

13. Ishikawa M, Kodama K, Yasuda H, Okamoto-Kainuma A, Koizumi K and Yamasato K:

Presence of halophilic and alkaliphilic lactic acid bacteria in various cheeses. Letters in Appl. Microbiol. 2006, 44 :308 - 313.

14. Mounier J, Monnet C, Jacques N, Antoinette A and Irlinger F :Assessment of the microbial diversity at the surface of Livarot cheese using culture-dependent and independent approaches. Int J Food Microbiol 2009, In press.

15. Sieuwerts S, de Bok FA, Hugenholtz J, van Hylckama Vlieg JET: Unravelling microbial interactions in food fermentations: from classical to genomics approaches. Appl Env Microbiol 2008, 74:4997-5007.

- Comprehensive review on important food fermentation processes. Focuses on microbial interactions.

16. Goerges S, Mounier J, Rea MC, Gelsomino R, Heise V, Beduhn R, Cogan TM, Vancanneyt M, Scherer S: Commercial ripening starter microorganisms inoculated into cheese milk do not successfully establish themselves in the resident microbial ripening consortia of a south German red smear cheese. Appl and Env Microbiol 2008, 74:22102217.

17. Mounier J, Goerges S, Gelsomino R, Vancanneyt M, Vandemeulebroecke K, Hoste B, Brennan NM, Scherer S, Swings J, Fitzgerald GF, Cogan TM: Sources of the adventitious microflora of a smear-ripened cheese. J Appl Microbiol 2006,101:668 - 681.

18. Mounier J, Monnet C, Vallaeys T, Arditi R, Sarthou AS, Hélias A, Irlinger F: Microbial interactions within a cheese microbial community. Appl Environ Microbiol 2008, 74:72181.

- The interactions within a cheese microbial community of nine species (three yeasts and six bacteria) in a model curd. After describing the growth of each member of this community 
during ripening, the Lotka-Volterra model is used as a preliminary approach to evaluate interand intra-species interactions. The effects of the omission of one, two or three yeasts on the growth and key functions (deacidification, utilisation of carbon sources, colour development) on the rest of the community are then evaluated. Y. lipolytica is found to influence mycelium formation in G. candidum. Yeasts are key species in bacterial development, but their influence on bacteria differs.

19. Jameson JE: A discussion of the dynamics of Salmonella enrichment, J Hygiene 1962, 60:193-207.

20. Guillier L, Stahl V, Hezard B, Notz E, Briandet R: Modelling the competitive growth between Listeria monocytogenes and biofilm microflora of smear cheese wooden shelves. Int J Food Microbiol 2008, 128:51-57.

- Describes the mechanism of the observed inhibition of Listeria monocytogenes by the natural biofilm microflora on wooden shelves used in the ripening of a soft and a smear cheese and referred to as the 'Jameson effect'.

21. Noordman WH, Reissbrodt R, Bongers RS, Rademaker JLW, Bockelmann W, Smit G: Growth stimulation of Brevibacterium sp. by siderophores. J Appl Microbiol 2006, 101:637-646.

22. Palková Z, Váchová L: Life within a community: benefit to yeast long-term survival. FEMS Microbiol Rev 2006, 30:806-824.

- The differentiation of yeast cells within a colony can be important for the long-term survival of a community under conditions of nutrient shortage. Colony development and physiology can be influenced by the environment. Described how a group of colonies can synchronise their developmental changes.

23. Gory K, Mortensen HD, Arneborg N and Jerspersen L: Ammonia production and its possible role as a mediator of communication for Debaryomyces hansenii and other cheese-relevant yeast species. J Dairy Sci 2007, 90:5032-5041.

24. Georgalaki MD, Van Den Berghe E, Kritikos D, Devreese B, Van Beeumen J, Kalantzopoulos G, De Vuyst L, Tsakalidou E: Macedocin, a food-grade lantibiotic produced by Streptococcus macedonicus ACA-DC 198. Appl Environ Microbiol 2002, 68:5891-903.

25. Anastasiou R, Georgalaki M, Manolopoulou E, Kandarakis I, De Vuyst L, Tsakalidou E: The performance of Streptococcus macedonicus ACA-DC 198 as starter culture in Kasseri cheese production. Int Dairy J 2007, 17: 208-217. 
26. O'Sullivan L, O'connor EB, Ross RP, Hill C: Evaluation of live-culture-producing lacticin 3147 as a treatment for the control of Listeria monocytogenes on the surface of smear-ripened cheese. $J$ Appl Microbiol 2006, 100:135-143.

27. Grattepanche F, Miescher-Schwenninger S, Meile L and Lacroix C: Recent developments in cheese cultures with protective and probiotic functionalities. Dairy Sci Technol 2008, 88:421-444.

- An excellent overview of the latest discoveries and challenges related to the application of protective cultures against pathogenic and spoilage microorganisms in cheese, as well as to the utilisation of cheese as a carrier of probiotic bacteria with health benefits.

28. Maoz A, Mayr R, Scherer S: Temporal stability and biodiversity of two complex antilisterial cheese-ripening microbial consortia. Appl Environ Microbiol 2003, 69:40124018.

29. Galaup P, Gautier A, Piriou Y, de Villeblanche A, Valla A, Dufossé L: First pigment fingerprints from the rind of French PDO red-smear ripened soft cheeses Epoisses, Mont d'Or and Maroilles. Innovat Food Sci Emerg Tech 2007, 8:373-378.

30. Leclercq-Perlat MN, Corrieu G, Spinnler HE: The color of Brevibacterium linens depends on the yeast used for cheese deacidification. J Dairy Sci 2004, 87:1536-1544.

31. van Hylckama Vlieg JET, Hugenholtz J: Mining natural diversity of lactic acid bacteria for flavour and health benefits. Int Dairy J 2007, 17:1290-1297.

32. Landaud S, Helinck S, Bonnarme P: Formation of volatile sulfur compounds and metabolism of methionine and other sulfur compounds in fermented food. Appl Microbiol Biotechnol 2008, 77:1191-1205.

33. Arfi K, Landaud S, Bonnarme P: Evidence for distinct L-methionine catabolic pathways in the yeast Geotrichum candidum and the bacterium Brevibacterium linens. Appl Environ Microbiol 2006, 72:2155-2162.

34. Kieronczyk A, Skeie S, Langsrud T, Yvon M: Cooperation between Lactococcus lactis and nonstarter lactobacilli in the formation of cheese aroma from amino acids. Appl Environ Microbiol 2003, 69:734-739.

35. Deetae P, Bonnarme P, Spinnler HE, Helinck S: Production of volatile aroma compounds by bacterial strains isolated from different surface-ripened French cheeses. Appl Microbiol Biotechnol 2007, 76:1161-1171.

36. Peláez C, Requena T: Exploiting the potential of bacteria in the cheese ecosystem. Int Dairy J 2005, 15:831-844. 
37. Martínez-Cuesta MC, Requena T, Peláez C: Permeabilization and lysis induced by bacteriocins and its effect on aldehyde formation by Lactococcus lactis. Biotechnol Lett 2006, 28:1573-1580.

38. Garde S, Avila M, Gaya P, Medina M, Nuñez M: Proteolysis of Hispanico cheese manufactured using lacticin 481-producing Lactococcus lactis ssp. lactis INIA 639. J Dairy Sci 2006, 8:840-849.

39. Bockelmann W, Willems P, Neve H, Heller KJ: Cultures for the ripening of smear cheeses. Int Dairy J 2005, 15:719-732.

40. De Angelis M, de Candia S, Calasso MP, Faccia M, Guinee TP, Simonetti MC, Gobbetti M: Selection and use of autochthonous multiple strain cultures for the manufacture of high-moisture traditional Mozzarella cheese. Int J Food Microbiol 2008, 125:123-132.

41. Mounier J, Fitzgerald GF, Cogan TM: Survival of surface ripening cultures during storage and monitoring their development on cheese. Lett Appl Microbiol 2006, 42:425431.

42. Ulve VM, Monnet C, Valence F, Fauquant J, Falentin H, Lortal S: RNA extraction from cheese for analysis of in situ gene expression of Lactococcus lactis. J Appl Microbiol 2008, 105:1327-1333.

43. Charlier C, Cretenet M, Even S, Leloir Y: Interactions between Staphylococcus aureus and lactic acid bacteria: an old story with new perspectives. Int J Food Microbiol 2009, in press doi:10.1016/j.ijfoodmicro.2008.06.032.

44. Gobetti M, De Angelis M, Di Cagno R, Minervini F, Limitone A: Cell-cell communication in food related bacteria. Int J Food Microbiol 2007, 120:34-45.

45. Monnet C, Ulvé V, Sarthou AS, Irlinger F: Extraction of RNA from cheese without prior separation of microbial cells. Appl Environ Microbiol 2008, 74:5724-5730.

46. Iseppi R, Pilati F, Marini M, Toselli M, de Niederhäusern S, Guerrieri E, Messi P, Sabia C, Manicardi G, Anacarso I, Bondi M: Anti-listerial activity of a polymeric film coated with hybrid coatings doped with Enterocin 416K1 for use as bioactive food packaging. Int J Food Microbiol 2008, 123:281-287.

47. Bizani D, Morrissy JA, Dominguez AP, Brandelli A: Inhibition of Listeria monocytogenes in dairy products using the bacteriocin-like peptide cerein $8 \mathrm{~A}$. Int J Food Microbiol 2008, 121:229-233.

48. Izquierdo E, Marchioni E, Aoude-Werner D, Hasselmann C, Ennahar S: Smearing of soft cheese with Enterococcus faecium WHE 81, a multi-bacteriocin producer, against Listeria monocytogenes. Food Microbiol 2009, 26:16-20. 
49. Reviriego C, Fernández L, Rodríguez JM: A food-grade system for production of pediocin PA-1 in nisin-producing and non-nisin-producing Lactococcus lactis strains: application to inhibit Listeria growth in a cheese model system. J Food Prot 2007, 70:2512-2517.

50. Liu L, O'Conner P, Cotter PD, Hill C, Ross RP: Controlling Listeria monocytogenes in Cottage cheese through heterologous production of enterocin A by Lactococcus lactis. $J$ Appl Microbiol 2008, 104:1059-1066. 
Table 1. Inventory of microbial interactions in cheeses

\begin{tabular}{lllll}
\hline $\begin{array}{l}\text { Interaction } \\
\text { types }\end{array}$ & $\begin{array}{l}\text { Effect in cheese and / or } \\
\text { molecules produced }\end{array}$ & $\begin{array}{l}\text { Microorganisms } \\
\text { involved }\end{array}$ & $\begin{array}{l}\text { Microbiological } \\
\text { phenomenon observed }\end{array}$ & References \\
\hline Commensalism & $\begin{array}{l}\text { Cheese-surface deacidification: } \\
\text { Lactic acid utilisation } \\
\text { Alcaline metabolites }\left(\mathrm{NH}_{3}\right) \\
\text { production }\end{array}$ & $\begin{array}{l}\text { Yeasts, ripening } \\
\text { bacteria }\end{array}$ & $\begin{array}{l}\text { Growth of acid-sensitive } \\
\text { bacteria }\end{array}$ & {$[18]$} \\
Amensalism & $\begin{array}{l}\text { Curd acidification } \\
\text { Organic acids (i.e. lactate) }\end{array}$ & $\begin{array}{l}\text { LAB, spoilage and } \\
\text { pathogenic bacteria }\end{array}$ & $\begin{array}{l}\text { Inhibition of acid-sensitive } \\
\text { bacteria }\end{array}$ & {$[15,27,44$,} \\
& Bacteriocins & $\begin{array}{l}\text { Lysis of pathogenic and } \\
\text { spoilage bacteria }\end{array}$ & {$[15,27]$} \\
Competition & Harvest of Iron & $\begin{array}{l}\text { Siderophores } \\
\text { containing bacteria, } \\
\text { auxotrophic bacteria }\end{array}$ & $\begin{array}{l}\text { Reduced colonization capacity } \\
\text { of auxotrophic strains }\end{array}$ & {$[21]$} \\
& Jameson effect & $\begin{array}{l}\text { Microbiota of wooden } \\
\text { shelves, Listeria } \\
\text { monocytogenes }\end{array}$ & $\begin{array}{l}\text { Limited colonization of } L . ~ \\
\text { monocytogenes }\end{array}$ & {$[20]$} \\
\hline & & Phage, bacteria & $\begin{array}{l}\text { Inactivation of dominant } \\
\text { strains }\end{array}$ & {$[15]$} \\
\hline
\end{tabular}

Abbreviations: LAB, lactic acid bacteria 
Table 2. Recent applications of bacteriocinogenic cultures and bacteriocins against $L$. monocytogenes in fresh or soft cheeses.

\begin{tabular}{|c|c|c|c|}
\hline Bacteriocin & Source organism & Mode of utilisation & References \\
\hline Enterocin 416K1 & Enterococcus casseliflavus & Bacteriocin entrapped in polymeric film & [46] \\
\hline Cerein $8 \mathrm{~A}$ & Bacillus cereus & Surface application of the bacteriocin & [47] \\
\hline Enterocin A and B & Enterococcus faecium & $\begin{array}{l}\text { Adjunct culture in brine and smearing } \\
\text { solution }\end{array}$ & [48] \\
\hline Lacticin 3147 & Lactococcus lactis & Smeared on the cheese surface & [26] \\
\hline $\begin{array}{l}\text { Nisin and Pediocin } \\
\text { PA-1 }\end{array}$ & $\begin{array}{l}\text { Recombinant Lactococcus } \\
\text { lactis }\end{array}$ & Starter culture & [49] \\
\hline Enterocin A & $\begin{array}{l}\text { Recombinant Lactococcus } \\
\text { lactis }\end{array}$ & Starter culture & [50] \\
\hline
\end{tabular}

